\title{
General Psychiatry Anticholinergic medications even in therapeutic range can cause recurrence of psychosis
}

\author{
Soumitra Das, ${ }^{1}$ Seshadri Sekhar Chatterjee (D) , \\ Barikar Chandrappa Malathesh (1) ${ }^{3}$
}

To cite: Das S, Chatterjee SS, Malathesh BC. Anticholinergic medications even in therapeutic range can cause recurrence of psychosis. General Psychiatry 2020;33:e100235. doi:10.1136/ gpsych-2020-100235

Received 03 April 2020 Revised 06 June 2020 Accepted 08 June 2020
Check for updates

(C) Author(s) (or their employer(s)) 2020. Re-use permitted under CC BY-NC. No commercial re-use. See rights and permissions. Published by BMJ.

${ }^{1}$ Psychiatry, NorthWestern Mental Health, Melbourne, Victoria, Australia ${ }^{2}$ Psychiatry, Diamond Harbour Medical College, Diamond Harbour, India

${ }^{3}$ Psychiatry, National Institute of Mental Health and Neuro Sciences, Bangalore, India

Correspondence to Dr Seshadri Sekhar Chatterjee; drsschatterjee@gmail.com

\section{ABSTRACT}

Anticholinergic drugs are commonly used in psychiatry to attenuate antipsychotic induced extrapyramidal syndrome (EPS). Psychosis as a side effect is generally explained under the rubric of anticholinergic toxicity or induced delirium. Anticholinergic induced worsening of psychosis in patients with normal cognition is extremely rare in literature. Here, we arepresenting a case of young female who was prescribed with multiple anticholinergics to reduce EPS, and each time had worsening of psychosis with intact cognition. We then discussed the possible neurobiological explanation with special reference to muscarinic hypothesis of schizophrenia.

\section{INTRODUCTION}

Anticholinergic drugs like trihexyphenidyl and procyclidine are often used in schizophrenia to combat antipsychotic-induced extrapyramidal syndrome (EPS). Even though this group of drugs has multiple side effects like constipation, blurring of vision and cognitive deficits, it is inadvertently prescribed in clinical practice. ${ }^{1}$ Toxicity due to its overdose has been described in the literature with presentation of mydriasis, drowsiness, urinary frequency, and, in severe cases, psychosis, convulsions, cardiorespiratory collapse and even death. Psychosis as a side effect is generally explained under the rubric of anticholinergic toxicity or induced delirium. ${ }^{12}$ Anticholinergic induced worsening of psychosis in patients with normal cognition is extremely rare in literature. Here, we present a case who was prescribed with multiple anticholinergics to reduce EPS, and each time, the person had worsening of psychosis with intact cognition.

\section{CASE HISTORY}

A woman aged 21 years, studying in a vocational school with a history of moderate mental retardation (IQ: 40) presented with irritability, decreased social interaction, auditory hallucination, persecutory and referential delusions, qualified for the diagnosis of schizophrenia (archaically pfropf schizophrenia). ${ }^{3}$ The patient also had extrapyramidal syndrome (EPS) (perioral movements which were probably due to the use of olanzapine $10 \mathrm{mg}$, given elsewhere). However, she was oriented to time, place and person.

In view of no improvement with $10 \mathrm{mg}$ of olanzapine and poor tolerance, she was started on aripiprazole $5 \mathrm{mg}$, which was gradually increased to $20 \mathrm{mg}$. On this dose, she had worsening of perioral lip movements and developed pill-rolling type of tremors in the hands. So, aripiprazole was decreased to $10 \mathrm{mg}$, but extrapyramidal symptoms persisted even after dose reduction. To counter EPS, she was started on trihexyphenidyl $2 \mathrm{mg}$.

On the same day, she had a significant worsening of psychotic symptoms like visual and auditory hallucinations, anger outbursts, fearfulness and aggressive behaviour; hence, trihexyphenidyl was stopped. One week later, she was started on procyclidine $2.5 \mathrm{mg}$ and she had similar exacerbation of psychotic symptoms, so it was also stopped. Five days later, she was again started on promethazine $25 \mathrm{mg}$ and she showed similar episodes of psychosis, so it was also stopped. As the patient was not tolerating anticholinergic and was not keen on changing aripiprazole, due to its benefits on psychosis, she was started on vitamin $\mathrm{E}$ for EPS. This time, she did not have any exacerbation of psychotic symptoms, but there was no improvement in her EPS even with $800 \mathrm{mg}$ of vitamin $\mathrm{E}$ for 1 month.

As the EPS was causing disturbances while taking food, she was started on tetrabenazine on which she showed partial improvement of EPS without worsening of psychotic symptoms. Hence, she waskept on $10 \mathrm{mg}$ of aripiprazole with $50 \mathrm{mg}$ of tetrabenazine. Her basic blood parameters and MRI were within normal limits. She never showed any sign of delirium in the whole period of treatment. 


\section{DISCUSSION}

Generally psychosis can be induced by anticholinergic drugs only when they are taken in dosages exceeding therapeutic range ${ }^{4}$ However, in our case, psychosis was induced within therapeutic dosage range itself with no other peripheral or cognitive anticholinegic symptoms. She was prescribed with three different anticholinergics, and each of them had led into psychotic relapses which subsided soon after inciting agent was withdrawn. This proves it as the causative factor as per Naranjo's score of $10 .^{5}$

As vitamin $\mathrm{E}$ and tetrabenazine have different mechanisms of action than anticholinergics, it did not show any psychotic relapses. This raises the suspicion of the underlying muscarinic hypothesis of schizophrenia, which states that there are decreased levels of M1 and M4 receptors in the hippocampus and the prefrontal cortex and its subsequent upregulation of neuroinflamatory activity. ${ }^{6}$ This also explains the negative and cognitive symptoms of schizophrenia. ${ }^{7}$ In subjects with schizophrenia, this could be a reason behind the worsening of psychotic symptoms. Moreover, there are evidences of reduced cholinergic activity in intellectual development disorder (IDD). ${ }^{8}$ So in this particular case, as we hypothesised, the patient already had diminished levels of acetylcholine due to IDD and schizophrenia, which, when further challenged with anticholinergic drugs, resulted in florid psychotic relapses even in its therapeutic dose range.

Hence, we should be cautious while prescribing anticholinergics to persons with both psychosis and IDD. Further studies in this area would be worthwhile.

Twitter Seshadri Sekhar Chatterjee @SeshadriSSC
Contributors SD: design, clinical data extraction and drafting of the study. SSC: conceptualisation, drafting, writing the manuscript, editing and intellectual content. BCM: editing, searching for data and writing.

Funding The authors have not declared a specific grant for this research from any funding agency in the public, commercial or not-for-profit sectors.

Competing interests None declared.

Patient consent for publication Obtained.

Provenance and peer review Not commissioned; externally peer reviewed.

Open access This is an open access article distributed in accordance with the Creative Commons Attribution Non Commercial (CC BY-NC 4.0) license, which permits others to distribute, remix, adapt, build upon this work non-commercially, and license their derivative works on different terms, provided the original work is properly cited, appropriate credit is given, any changes made indicated, and the use is non-commercial. See: http://creativecommons.org/licenses/by-nc/4.0/.

ORCID iDs

Seshadri Sekhar Chatterjee http://orcid.org/0000-0002-5554-2216

Barikar Chandrappa Malathesh http://orcid.org/0000-0001-9107-1717

\section{REFERENCES}

1 Minton JA, Tofade TS, Shah SA, et al. Psychosis from anticholinergic medications administered at a smoking cessation clinic. J Pharm Pract 2009;22:489-93.

2 Hamdan-allen G. Anticholinergic psychosis in children : a case report. Hosp Comm Psych 1991;42:1990-2.

3 Mack AH, Feldman JJ, Tsuang MT. A case of "pfropfschizophrenia": Kraepelin's bridge between neurodegenerative and neurodevelopmental conceptions of schizophrenia. Am J Psychiatry 2002;159:1104-10.

4 Tom NR, Varghese $\mathrm{GH}$, Alexander $\mathrm{H}$, et al. A case report on atropine induced psychosis. Int J Pharm Sci Res 2016;7:387.

5 Naranjo CA, Busto U, Sellers EM, et al. A method for estimating the probability of adverse drug reactions. Clin Pharmacol Ther 1981;30:239-45.

6 Raedler TJ, Bymaster FP, Tandon R, et al. Towards a muscarinic hypothesis of schizophrenia. Mol Psychiatry 2007;12:232-46.

7 Scarr E, Gibbons AS, Neo J, et al. Cholinergic connectivity: it's implications for psychiatric disorders. Front Cell Neurosci 2013;7:55.

8 Perry EK, Lee ML, Martin-Ruiz CM, et al. Cholinergic activity in autism: abnormalities in the cerebral cortex and basal forebrain. $A m \mathrm{~J}$ Psychiatry 2001;158:1058-66.

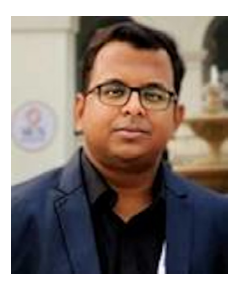

Dr Seshadri Sekhar Chatterjee is an Assistant Professor and Consultant Psychiatrist in West Bengal, India. He obtained his MD degree from Institute of Psychiatry, Kolkata, Diplomate in National Board (DNB) from National Board of Examinations (NBE), Delhi and finished his Postdoctoral fellowship in Geriatric Psychiatry from National Institute of Mental Health and Neurosciences (NIMHANS), Bangalore. He has multiple publications in international journals and also works as a reviewer in many reputed journals. His main research interests include organic psychiatry, neuropsychiatry, psychopharmacology and geriatric psychiatry. 